\title{
Front Matter: Volume 11217
}

, "Front Matter: Volume 11217," Proc. SPIE 11217, Lasers in Dentistry XXVI, 1121701 (27 February 2020); doi: 10.1117/12.2569594

SPIE. Event: SPIE BiOS, 2020, San Francisco, California, United States 
PROGRESS IN BIOMEDICAL OPTICS AND IMAGING

Vol. 21 No. 7

\section{Lasers in Dentistry XXVI}

\section{Peter Rechmann}

Daniel Fried

Editors

2 February 2020

San Francisco, California, United States

Sponsored and Published by

SPIE 
The papers in this volume were part of the technical conference cited on the cover and title page. Papers were selected and subject to review by the editors and conference program committee. Some conference presentations may not be available for publication. Additional papers and presentation recordings may be available online in the SPIE Digital Library at SPIEDigitalLibrary.org.

The papers reflect the work and thoughts of the authors and are published herein as submitted. The publisher is not responsible for the validity of the information or for any outcomes resulting from reliance thereon.

Please use the following format to cite material from these proceedings:

Author(s), "Title of Paper," in Lasers in Dentistry XXVI, edited by Peter Rechmann, Daniel Fried, Proceedings of SPIE Vol. 11217 (SPIE, Bellingham, WA, 2019) Seven-digit Article CID Number.

ISSN: $1605-7422$

ISSN: 2410-9045 (electronic)

ISBN: 9781510631977

ISBN: 9781510631984 (electronic)

Published by

SPIE

P.O. Box 10, Bellingham, Washington 98227-0010 USA

Telephone +1 3606763290 (Pacific Time) · Fax +1 3606471445

SPIE.org

Copyright (c) 2020, Society of Photo-Optical Instrumentation Engineers.

Copying of material in this book for internal or personal use, or for the internal or personal use of specific clients, beyond the fair use provisions granted by the U.S. Copyright Law is authorized by SPIE subject to payment of copying fees. The Transactional Reporting Service base fee for this volume is $\$ 21.00$ per article (or portion thereof), which should be paid directly to the Copyright Clearance Center (CCC), 222 Rosewood Drive, Danvers, MA 01923. Payment may also be made electronically through CCC Online at copyright.com. Other copying for republication, resale, advertising or promotion, or any form of systematic or multiple reproduction of any material in this book is prohibited except with permission in writing from the publisher. The CCC fee code is 1605$7422 / 20 / \$ 21.00$.

Printed in the United States of America by Curran Associates, Inc., under license from SPIE.

Publication of record for individual papers is online in the SPIE Digital Library.

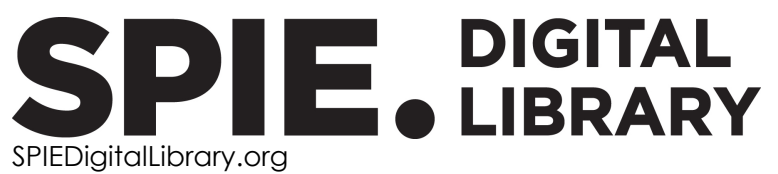

SPIEDigitalLibrary.org

Paper Numbering: Proceedings of SPIE follow an e-First publication model. A unique citation identifier (CID) number is assigned to each article at the time of publication. Utilization of CIDs allows articles to be fully citable as soon as they are published online, and connects the same identifier to all online and print versions of the publication. SPIE uses a seven-digit CID article numbering system structured as follows:

- The first five digits correspond to the SPIE volume number.

- The last two digits indicate publication order within the volume using a Base 36 numbering system employing both numerals and letters. These two-number sets start with 00, 01, 02, 03, 04, 05, 06, 07, 08, 09, OA, OB ... 0Z, followed by 10-1Z, 20-2Z, etc. The CID Number appears on each page of the manuscript. 


\section{Contents}

$\begin{aligned} \vee & \text { Authors } \\ \text { vii } & \text { Conference Committee }\end{aligned}$

\section{SESSION 1 LASER IN EROSION REDUCTION, THERMAL IMAGING OF DENTAL MATERIALS, BLEACHING AND} PLAQUE PH MEASUREMENT

1121703 Assessment of thermal changes in different restorative materials using a thermal camera [11217-2]

1121704 Diode activated home bleaching techniques with stereolithographic models and trays [11217-3]

SESSION 2 LASER IN ACID RESISTANCE, OCT AND ADAPTION OF RESTORATIONS, CARIES DETECTION AND ITS VALIDATION AND IMAGING

1121706 Optical Coherence Tomography (OCT) for the evaluation of internal adaptation of class $V$ resin restorations on dentin [11217-6]

1121708 SWIR, thermal and CP-OCT imaging probes for the in vivo assessment of the activity of root caries lesions [1 1217-8]

SESSION 3 LLT AND PERIODONTAL LIGAMENT, PS-OCT IN ORAL TISSUES WITH PRECANCEROUS AND CANCEROUS LESIONS

1121709 Evaluation of low level laser therapy, platelet rich plasma, and their combination on the proliferation rate of human periodontal ligament fibroblast: an in vitro study [11217-9]

$11217 \mathrm{OB} \quad \mathrm{A}$-scan spectral intensity profile in OCT as a potential imaging biomarker of oral precancerous and cancerous tissues [11217-11]

\section{POSTER SESSION}

$11217 \mathrm{OE} \quad$ Classification of pit and fissure for caries risk based on 3D surface morphology analysis of tooth [11217-14]

11217 OG Optimization methods for deep neural networks classifying OCT images to detect dental caries [11217-16]

$11217 \mathrm{OH}$ A thermal imaging handpiece for the clinical assessment of lesion activity on root surfaces via dehydration [11217-17] 
11217 ol A SWIR imaging handpiece for the clinical assessment of lesion activity via dehydration: preclinical assessment [1 1217-18]

$112170 \mathrm{~J} \quad$ A dual handheld SWIR transillumination/reflectance probe for imaging lesions on tooth occlusal and proximal surfaces [11217-19]

11217 OK In vivo spectral guided removal of composite from tooth surfaces with a $\mathrm{CO}_{2}$ laser [1 1217-20] 


\title{
Authors
}

Numbers in the index correspond to the last two digits of the seven-digit citation identifier (CID) article numbering system used in Proceedings of SPIE. The first five digits reflect the volume number. Base 36 numbering is employed for the last two digits and indicates the order of articles within the volume. Numbers start with 00, 01, 02, 03, 04, 05, 06, 07, 08, 09, OA, OB...0Z, followed by 10-1Z, 20-2Z, etc.

\author{
Abdelaziz, Marwa, 06 \\ Ahuja, Shelly, 09 \\ Bakhsh, Anas, 03 \\ Bakhsh, Turki A., 03 \\ Banan, Prajna, 08 \\ Barchini, Majd, OG \\ Betancourt, Francisco, 06 \\ Bhatt, Kishore, 09 \\ Bortolotto, Tissiana, 06 \\ Bradna, Pavel, 04 \\ Chang, Nai-Yuan, 08, OH, Ol, OJ \\ Chen, Qingguang, OE \\ Choi, Jye Hye, OK \\ Curtis, Donald, 08 \\ Darling, Cynthia L., 08 \\ Dostalova, Tatjana, 04 \\ Fried, Daniel, 06, 08, 0H, OI, 0J, OK \\ Fried, William A., 08, 0I, 0J \\ Jamleh, Ahmad, 03 \\ Jang, Andrew, OK \\ Jelinkova, Helena, 04 \\ Jin, Xing, OE \\ John, Renu, OB \\ Kratochvil, Jan, 04 \\ Krejci, Ivo, 06 \\ Kumar, Pawan, $\mathrm{OB}$ \\ Le, Oanh, 08 \\ Madhukar, Pankaj, 09 \\ Mahdian, Mina, OG \\ Nemec, Michal, 04 \\ Nocar, Adam, 04 \\ Panta, Prashanth, OB \\ Pecenka, Jiri, 04 \\ Riha, Adam, 04 \\ Salehi, Hassan S., OE, OG \\ Sarode, Sachin, OB \\ Shokry, Yousef, 03 \\ Simon, Jacob C., 08, 0K \\ Sulc, Jan, 04 \\ Yang, Vicent B., 08, 0H, Ol, 0J \\ Zhu, Haihua, OE \\ Zhu, Yihua, 08, 0l, 0J \\ Zuluaga, Andrés F., 06
}


Proc. of SPIE Vol. 11217 1121701-6

\section{Downloaded From: https://www.spiedigitallibrary.org/conference-proceedings-of-spie on 26 Apr 2023
Terms of Use: https://www.spiedigitallibrary.org/terms-of-use}




\title{
Conference Committee
}

\author{
Symposium Chairs
}

Jennifer K. Barton, The University of Arizona (United States)

Wolfgang Drexler, Medizinische Universität Wien (Austria)

Program Track Chairs

Brian Jet-Fei Wang, Beckman Laser Institute and Medical Clinic,

University of California, Irvine (United States)

Eva Sevick, The University of Texas Health Science Center at Houston

(United States)

Conference Chairs

Peter Rechmann, University of California, San Francisco

(United States)

Daniel Fried, University of California, San Francisco (United States)

Conference Program Committee

Gregory B. Altshuler, IPG Medical Corporation (United States)

Tatjána Dostálová, Charles University in Prague (Czech Republic)

Thomas Ertl, Universität Stuttgart (Germany)

David M. Harris, Bio-Medical Consultants, Inc. (United States)

Jörg Meister, Universitätsklinikum Bonn (Germany)

Eric J. Seibel, University of Washington (United States)

\section{Session Chairs}

1 Laser in Erosion Reduction, Thermal Imaging of Dental Materials,

Bleaching and Plaque $\mathrm{pH}$ Measurement

Peter Rechmann, University of California, San Francisco

(United States)

2 Laser in Acid Resistance, OCT and Adaption of Restorations, Caries

Detection and its Validation and Imaging

Daniel Fried, University of California, San Francisco (United States)

3 LLT and Periodontal Ligament, PS-OCT in Oral Tissues with

Precancerous and Cancerous Lesions

Peter Rechmann, University of California, San Francisco

(United States) 
Proc. of SPIE Vol. 11217 1121701-8

\section{Downloaded From: https://www.spiedigitallibrary.org/conference-proceedings-of-spie on 26 Apr 2023
Terms of Use: https://www.spiedigitallibrary.org/terms-of-use}

